\begin{tabular}{c|l|l|l}
$\begin{array}{c}\text { Case Reports in } \\
\text { Oncology }\end{array}$ & $\begin{array}{l}\text { Case Rep Oncol 2011;4:149-154 } \\
\text { DOI: 10.1159/000326067 }\end{array}$ & $\begin{array}{l}\text { Published online: } \\
\text { March 18, 2011 }\end{array}$ & $\begin{array}{l}\text { O 2011 S. Karger AG, Basel } \\
\text { ISSN 1662-6575 } \\
\text { www.karger.com/cro }\end{array}$ \\
\hline
\end{tabular}

\title{
Mixed Adenocarcinoma of the Rectovaginal Septum Associated with Endometriosis and Endometrial Carcinoma: A Case Report
}

\author{
Mohamed Mabrouk $^{\mathrm{a}, \mathrm{c}} \quad$ Claudia Vicenzi $^{\mathrm{a}} \quad$ Giulia Ferrini $^{\mathrm{a}}$ \\ Elisa Geracia Simona Del Forno ${ }^{a} \quad$ Giacomo Caprarab

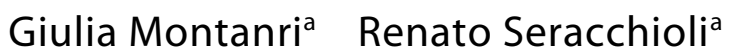

${ }^{a}$ Minimally Invasive Gynecological Surgery Unit, Department of Gynaecology, and ${ }^{b}$ Department of Anatomo-Pathology, S. Orsola-Malpighi Hospital, Bologna University, Bologna, Italy; 'Department of Obstetrics and Gynecology, Alexandria University, Alexandria, Egypt

\section{Key Words}

Adenocarcinoma Clear cell carcinoma Endometrioid carcinoma $\cdot$ Endometriosis . Rectovaginal septum · Laparoscopy

\begin{abstract}
Purpose: To present a case of primary mixed (clear cell and endometrioid type) adenocarcinoma of the rectovaginal septum, probably arising from endometriosis and associated with a highly differentiated, early-stage endometrioid endometrial carcinoma. The case was managed by a minimally invasive approach and postoperative adjuvant chemotherapy.
\end{abstract}

Results: The patient underwent clinical/instrumental follow-up and a second-look laparoscopy after the primary surgery as well as adjuvant chemotherapy. No evidence of disease could be observed after the treatment.

Conclusion: Surgery with postoperative chemotherapy can be recommended for the treatment of mixed adenocarcinoma of the rectovaginal septum.

\section{Introduction}

Although endometriosis cannot be termed a premalignant disease, epidemiologic, histopathologic and molecular data suggest that this condition does have malignant potential [1]. In the literature, 14 cases of primary adenocarcinoma of the rectovaginal 
septum have been described. The most frequent histological type is papillary adenocarcinoma; adenoacanthomas or clear cell adenocarcinomas are less common $[2,3]$. The most common treatment approach consists of surgery in combination with either neoadjuvant or adjuvant radiation therapy $[2,4-6]$.

We report the case of a young woman with mixed (clear cell and endometrioid type) adenocarcinoma of the rectovaginal septum associated with benign endometriosis, adenomyosis and with foci of endometrioid endometrial adenocarcinoma (G1, stage Ia).

\section{Case Report}

A 36-year-old nulliparous Caucasian woman complained of abdominal discomfort. A CT scan was performed and a $75 \times 40 \mathrm{~mm}$ retro-uterine mass, probably of ovarian origin, was reported on the left paramedian side. The patient's past medical and surgical history was uneventful and her gynaecological history was characterized by irregular and copious menstrual cycles. Consequently, she was referred to our out-patient oncology clinic with the suspicion of an ovarian mass. The patient did not complain of painful, perimenstrual symptoms suggestive of endometriosis.

On clinical examination, the pelvis was almost completely occupied by a solid, painful, retrocervical mass, adherent to the vaginal apex and involving the rectovaginal septum. The uterus was poorly mobile and no palpated adnexal masses were observed. An ultrasound scan revealed that both ovaries were slightly enlarged and prolapsed into the Douglas pouch, with no ovarian masses. They were adherent to a big, solid, retrocervical mass with a mean diameter of $85 \mathrm{~mm}$, internal hyperechoic areas, irregular external profile, no cleavage planes with surrounding tissues and with marked vascularisation at power Doppler imaging. The endometrial layer was thickened and irregular. The ultrasound exploration of the pelvic and abdominal peritoneum revealed mild ascites with no peritoneal implants or other masses. A chest X-ray was unremarkable, while serum levels of Ca125 and Ca19.9 were markedly elevated. After a comprehensive counseling, the patient was scheduled for laparoscopic biopsy of the mass, the ovaries and the endometrium, with subsequent frozen section (FS) examination. The patient was also fully informed about the surgical plans according to the FS outcomes or the laparoscopic findings. An informed consent was obtained, and before laparoscopy, a fractional curettage was performed.

At diagnostic laparoscopy (fig. 1), we found an 8-cm rectovaginal mass invading the parietal peritoneum of the Douglas pouch, with an irregular cauliflower surface, marked superficial vascularisation and poor cleavage planes with the ovaries, the posterior isthmic wall and the rectum. The ovaries were slightly enlarged, adherent to the previously described mass, with superficial endometriotic implants on their surfaces. On the peritoneum of the Douglas pouch, superficial brown implants suggestive of peritoneal endometriosis were present. Other abdominal organs and the peritoneum were macroscopically normal. Mild ascitic fluid was found. A peritoneal fluid sample was collected and sent for cytological examination. Biopsy specimens were taken from the rectovaginal mass, from both ovaries and from the pelvic peritoneum. Laparoscopic biopsies were removed separately through the right lateral trocar using endobags. All biopsies were sent for FS analysis, which showed that the retro-uterine mass and the pelvic peritoneum were infiltrated by a poorly differentiated adenocarcinoma. The endometrial biopsy revealed endometrial hyperplasia with foci of endometrioid carcinoma. Both ovarian biopsy specimens were free from neoplasia.

Based on the results from the FS examination, the patient underwent laparoscopic/minilaparotomic resection of the mass, radical hysterectomy, pelvic peritonectomy, pelvic and lumboaortic lymphadenectomy, omentectomy, rectal resection with a low pelvic colorectal anastomosis protected by ileostomy, and appendicectomy. There was no evidence of macroscopic disease at the end of surgery. There were no intraoperative complications and the postoperative course was uneventful. The patient was discharged on postoperative day 7 . Subsequently, she underwent 1 cycle of carboplatin + paclitaxel chemotherapy, which, however, had to be interrupted for allergic reaction and replaced by 2 cycles of cisplatinum chemotherapy. A second-look procedure with closure of the ileostomy was done 2 months later. There was no evidence of disease. 


\begin{tabular}{r|l|l|l}
$\begin{array}{c}\text { Case Reports in } \\
\text { Oncology }\end{array}$ & $\begin{array}{l}\text { Case Rep Oncol 2011;4:149-154 } \\
\text { DOI: 10.1159/000326067 }\end{array}$ & $\begin{array}{l}\text { Published online: } \\
\text { March 18, 2011 }\end{array}$ & $\begin{array}{l}\text { O 2011 S. Karger AG, Basel } \\
\text { ISSN 1662-6575 } \\
\text { www.karger.com/cro }\end{array}$ \\
\hline
\end{tabular}

\section{Results}

Grossly, the tumour was haemorrhagic, necrotic, with irregular outlines, growing posterior to the uterus and the cervix. The uterus was enlarged $(7.5 \times 4 \times 3.5 \mathrm{~cm})$, as were both ovaries, which presented with multiple, round, dark brownish cysts. The pelvic peritoneum showed multiple yellow-tan solid nodules measuring up to $1.5 \mathrm{~cm}$.

Microscopically, the tumour composed of epithelial cells with severe atypia arranged in a glandular and solid pattern with endometrioid differentiation; a clear cell differentiation was also present in the lesion. The endometrial component was represented in about $80 \%$ (fig. 2) and the clear cell component in about $20 \%$ of the mass (fig. 3). Special staining revealed abundant periodic acid-Schiff cytoplasmatic positivity, with numerous cytoplasmatic vacuoles positive for mucin. Immunohistochemical results for CK7 and ER receptor showed positivity only in the endometrioid component; vimentin, however, was strongly positive in the endometrioid component and focally positive in clear cells. In the endometrium, a well-differentiated (G1) endometrioid carcinoma with a villoglandular pattern of the anterior uterine wall could be found. The lesion showed superficial infiltration (M1). On the myometrial level, diffuse adenomyosis with an intact serosal surface was identified. The carcinoma did not involve the ovaries, which, however, both showed foci of endometriosis.

\section{Discussion}

Primary adenocarcinoma of the rectovaginal septum is a very rare pathological entity. Most of the patients (70\%) develop their malignancies in the setting of endometriosis. In 1925, Sampson [7] first reported 7 cases of malignant transformation of endometriosis to adenocarcinoma and postulated the following criteria to define a neoplasm originating from endometriosis: (1) the histological type of the neoplasm must be compatible with an endometrial origin, (2) no other primary site should be found, and (3) endometriosis must be adjacent to the neoplasm. Because our case fulfilled all these criteria, we hypothesized that the retrouterine adenocarcinoma was a malignant transformation of rectovaginal septum endometriosis. In addition, our patient had a well-differentiated, early-stage endometrioid adenocarcinoma with myometrial infiltration of less than $50 \%$ in the anterior uterine wall. Hence, a theory of direct spread from the endometrial malignancy can be excluded.

Because of the small number of reported cases with rectovaginal septum tumours, there is no consensus regarding the optimal treatment of this disease. Traditionally, the management involved surgery in combination with either neoadjuvant or adjuvant radiation therapy [2-6]. The most frequent histological types and treatments are summarized in table 1.

\section{Conclusion}

In conclusion, we want to emphasize 3 issues regarding this case: (1) the malignant potential of endometriosis and the existence of a mixed histological type of the rectovaginal adenocarcinoma ( $80 \%$ endometrioid and $20 \%$ clear cell carcinoma); (2) the concomitant presence of a highly differentiated endometrial carcinoma of the uterine 


\begin{tabular}{r|l|l|l}
$\begin{array}{c}\text { Case Reports in } \\
\text { Oncology }\end{array}$ & $\begin{array}{l}\text { Case Rep Oncol 2011;4:149-154 } \\
\text { DOl: 10.1159/000326067 }\end{array}$ & $\begin{array}{l}\text { Published online: } \\
\text { March 18, 2011 }\end{array}$ & $\begin{array}{l}\text { O 2011 S. Karger AG, Basel } \\
\text { ISSN 1662-6575 } \\
\text { www.karger.com/cro }\end{array}$ \\
\hline
\end{tabular}

body and a carcinoma of the rectovaginal septum, and (3) the importance of the one-step, minimally invasive management of the case after comprehensive counseling and FS examination.

Table 1. Histological types and treatments of rectovaginal septum tumours

\begin{tabular}{|c|c|c|c|c|c|}
\hline $\begin{array}{l}\text { Case } \\
\text { No. }\end{array}$ & Reference, year & $\begin{array}{l}\text { Age } \\
\text { years }\end{array}$ & Histological type & Treatment & Follow-up \\
\hline 1 & Hoeppner [8], 1931 & 43 & Unknown & RT & Unknown \\
\hline 2 & Vogt [9], 1937 & 53 & Unknown & & NR 10 months \\
\hline 3 & Dockerty et al. [10], 1954 & 54 & Unknown & $\mathrm{TH}+\mathrm{BSO}+\mathrm{LN} / \mathrm{RT}$ & DOD 2 years \\
\hline 4 & Dockerty et al. [10], 1954 & 45 & Unknown & $\mathrm{TH}+\mathrm{BSO}+\mathrm{LN} / \mathrm{RT}$ & NR 10 years \\
\hline 5 & Ferreira and Clayton [11], 1958 & 44 & Unknown & $\mathrm{TH}+\mathrm{BSO}$ & NR 3 years \\
\hline 6 & Lash and Rubenstone [12], 1959 & 35 & Unknown & Cervicectomy, RR & Unknown \\
\hline 7 & Davis [13], 1967 & & Unknown & $\mathrm{TH}+\mathrm{RR}$ & $\begin{array}{l}\text { Died } 11 \text { months later } \\
\text { of pelvic recurrence }\end{array}$ \\
\hline 8 & Young and Gamble [14], 1969 & 47 & Adenoacanthoma & Pelvic exenteration+RT & Unknown \\
\hline 9 & Goldberg et al. [3], 1978 & Unknown & Clear cell adenocarcinoma & $\begin{array}{l}\mathrm{TH}+\mathrm{LN}+\mathrm{RR}+\text { resection of the } \\
\text { upper half of the vagina }\end{array}$ & \\
\hline 10 & Addison et al. [15], 1979 & 56 & Unknown & $\mathrm{RT} / \mathrm{CT}$ & DOD 1 years \\
\hline 11 & Yazbeck et al. [6], 2005 & 25 & Papillary adenocarcinoma & $\mathrm{RT} / \mathrm{TH}+\mathrm{RR}$ & NR 2 years \\
\hline 12 & Berger et al. [4], 2001 & 58 & $\begin{array}{l}\text { Acinar and papillary } \\
\text { adenocarcinoma }\end{array}$ & $\mathrm{TH}+\mathrm{BSO}+\mathrm{RR}+$ colpectomy $+\mathrm{RT}$ & RE 5 years later \\
\hline 13 & Ulrich et al. [5], 2005 & 51 & $\begin{array}{l}\text { Glandular and papillary } \\
\text { tumor }\end{array}$ & $\begin{array}{l}\mathrm{RR}+\mathrm{BSO}+\text { vagina and } \\
\text { parakolpium resection+LN+RT }\end{array}$ & RE 2 years later \\
\hline 14 & Guiou et al. [2], 2008 & 52 & Clear cell adenocarcinoma & $\mathrm{CT}$ & NR \\
\hline
\end{tabular}

$\mathrm{RT}=$ Radiation therapy; $\mathrm{TH}=$ total hysterectomy; $\mathrm{BSO}=$ bilateral salpingo-oophorectomy $\mathrm{LN}=$ lymph node dissection; $\mathrm{CT}=$ chemotherapy; $\mathrm{RR}=$ rectal resection; $\mathrm{RE}=$ recurrence; $\mathrm{NR}=$ no recurrence; $\mathrm{DOD}=$ dead of disease. 


\begin{tabular}{c|l|l|l}
$\begin{array}{c}\text { Case Reports in } \\
\text { Oncology }\end{array}$ & $\begin{array}{l}\text { Case Rep Oncol 2011;4:149-154 } \\
\text { DOl: 10.1159/000326067 }\end{array}$ & $\begin{array}{l}\text { Published online: } \\
\text { March 18, 2011 }\end{array}$ & $\begin{array}{l}\text { O 2011 S. Karger AG, Basel } \\
\text { ISSN 1662-6575 } \\
\text { www.karger.com/cro }\end{array}$ \\
\hline
\end{tabular}

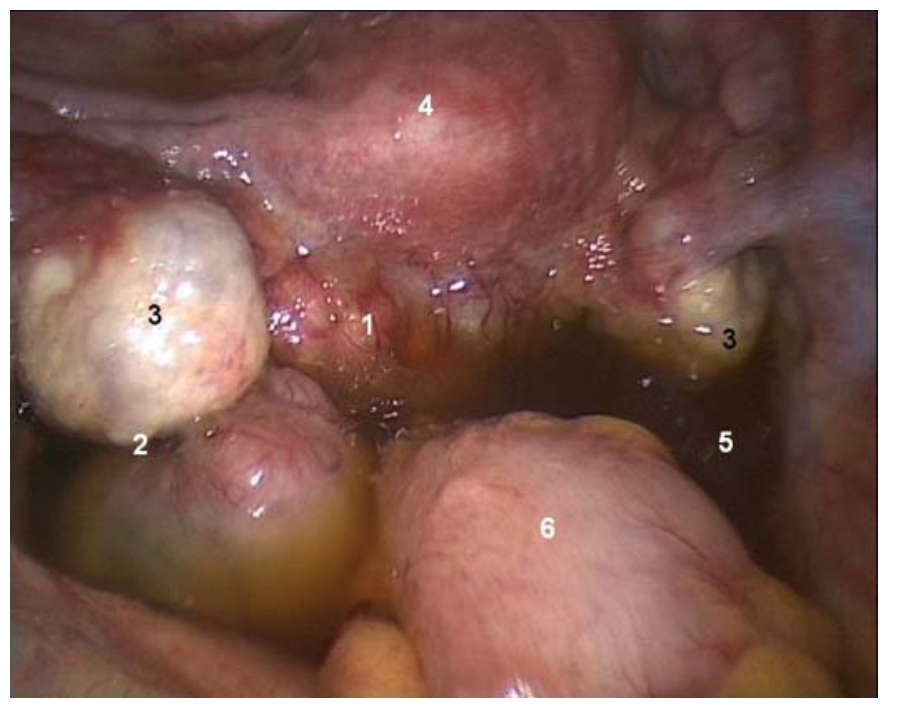

Fig. 1. Diagnostic laparoscopic findings. (1) Rectovaginal mass. (2) Peritoneal endometriosis. (3) Slightly enlarged ovaries. (4) Uterus. (5) Ascites. (6) Rectum.

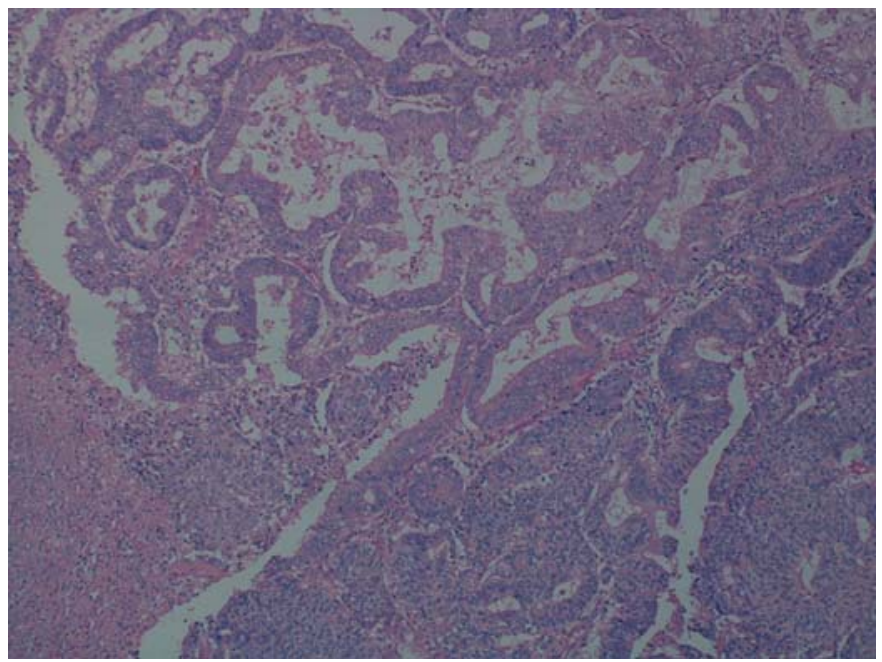

Fig. 2. Mixed epithelial tumour: endometrioid carcinoma with a solid growth pattern (HE). 


\begin{tabular}{c|l|l|l}
$\begin{array}{c}\text { Case Reports in } \\
\text { Oncology }\end{array}$ & $\begin{array}{l}\text { Case Rep Oncol 2011;4:149-154 } \\
\text { DOI: 10.1159/000326067 }\end{array}$ & $\begin{array}{l}\text { Published online: } \\
\text { March 18, 2011 }\end{array}$ & $\begin{array}{l}\text { O 2011 S. Karger AG, Basel } \\
\text { ISSN 1662-6575 } \\
\text { www.karger.com/cro }\end{array}$ \\
\hline
\end{tabular}

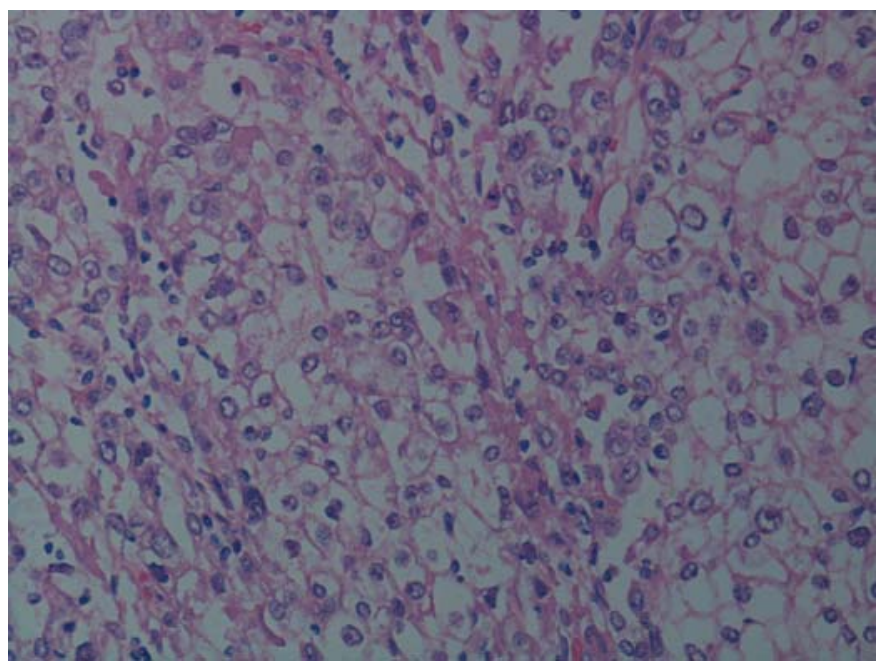

Fig. 3. Mixed epithelial tumour: clear cell carcinoma. The tumour cells contain glycogen which is stained by periodic acid-Schiff (HE).

\section{References}

1 Nezhat F, Datta MS, Hanson V, Pejovic T, Nezhat C, Nezhat C: The relationship of endometriosis and ovarian malignancy: a review. Fertil Steril 2008;90:1559-1570.

2 Guiou M, Hall WH, Konia T, Scudder S, Leiserowitz G, Ryu JK: Primary clear cell adenocarcinoma of the rectovaginal septum treated with concurrent chemoradiation therapy: a case report. Int J Gynecol Cancer 2008; 18:1118-1121.

3 Goldberg MI, Belinson JL, Hutson ED, Nordqvist SR: Clear cell adenocarcinoma arising in endometriosis of the rectovaginal septum. Obstet Gynecol 1978;51(1 suppl):38s-40s.

4 Berger A, Rouzier R, Carnot F, Braunberger E, Cugnenc PH, Danel C: Primary adenocarcinoma of the rectovaginal septum: a case report and literature review. Eur J Obstet Gynecol Reprod Biol 2001;95:111-113.

5 Ulrich U, Rhiem K, Kaminski M, Wardelmann E, Trog D, Valter M, Richter ON: Parametrial and rectovaginal adenocarcinoma arising from endometriosis. Int J Gynecol Cancer 2005;15:1206-1209.

6 Yazbeck C, Poncelet C, Chosidow D, Madelenat P: Primary adenocarcinoma arising from endometriosis of the rectovaginal septum: a case report. Int J Gynecol Cancer 2005;15:1203-1205.

$\checkmark 7$ Sampson JA: Endometrial carcinoma of the ovary arising in endometrial tissue of that organ. Arch Surgery 1925;10:1-72.

8 Hoeppner H: Beitrag zur Adenofibrosis retrocervicalis, insbesondere zur Frage des Spätüberganges derselben in Karzinom. Monatsschr Geburtsh Gynäkol 1931;87:536-545.

9 Vogt E: Karzinom auf der Basis einer Endometriosis. Z Gynäkol 1937;61:54-55.

10 Dockerty MB, Pratt JH, Decker DG: Primary adenocarcinoma of the rectovaginal septum probably arising from endometriosis; report of two cases. Cancer 1954;7:893-898.

11 Ferreira HP, Clayton SG: Three cases of malignant change in endometriosis, including two cases arising in the recto-vaginal septum. J Obstet Gynaec Br Emp 1958;65:41-44.

12 Lash SR, Rubenstone AI: Adenocarcinoma of the rectovaginal septum probably arising from endometriosis. Am J Obstet Gynec 1959;78:299-302.

13 Davis JM: Carcinoma in the rectovaginal septum. Proc R Soc Med 1967;60:502.

14 Young EE, Gamble CN: Primary adenocarcinoma of the rectovaginal septum arising from endometriosis. Report of a case. Cancer 1969;24:597-601.

15 Addison WA, Hammond CB, Parker RT: The occurrence of adenocarcinoma in endometriosis of the rectovaginal septum during progestational therapy. Gynecol Oncol 1979;8:193-197. 